\title{
Expression of TRPC6 channels in human epithelial breast cancer cells
}

\author{
Arnaud Guilbert ${ }^{\dagger 1}$, Isabelle Dhennin-Duthille ${ }^{\dagger 1}$, Yassine EL Hiani ${ }^{1}$, \\ Nathalie Haren ${ }^{1}$, Hafida Khorsi ${ }^{2}$, Henri Sevestre ${ }^{1,3}$, Ahmed Ahidouch ${ }^{1,4}$ and \\ Halima Ouadid-Ahidouch*1
}

\begin{abstract}
Address: ${ }^{1}$ Laboratoire de Physiologie Cellulaire et Moléculaire, JE « Canaux ioniques dans le cancer du sein », Faculté des Sciences, Université de Picardie Jules Verne, 33 Rue St Leu 80039, Amiens, France, ²Dysrégulations Métaboliques Acquises et Génétiques, Faculté de Médecine, Université de Picardie Jules Verne, 3 rue des Louvels, 80036, Amiens, France, ${ }^{3}$ Service d Anatomie Pathologique, CHU Nord, Amiens, France and ${ }^{4}$ Laboratoire de Physiologie Animale, Faculté des Sciences, Université Ibn-Zohr, Agadir, Morocco

Email: Arnaud Guilbert - arnaud.guilbert@etud.u-picardie.fr; Isabelle Dhennin-Duthille - isabelle.dhennin@u-picardie.fr;

Yassine EL Hiani - yassine.elhiani@u-picardie.fr; Nathalie Haren - nathalie.haren@u-picardie.fr; Hafida Khorsi - hafida.khorsi@u-picardie.fr; Henri Sevestre - Sevestre.Henri@chu-amiens.fr; Ahmed Ahidouch - ahmed.ahidouch@u-picardie.fr; Halima Ouadid-Ahidouch* - hasciences@u-picardie.fr

* Corresponding author †Equal contributors
\end{abstract}

Published: 2 May 2008

BMC Cancer 2008, 8:125 doi:10.1186/147|-2407-8-125

This article is available from: http://www.biomedcentral.com/I47/-2407/8/125

(c) 2008 Guilbert et al; licensee BioMed Central Ltd.

This is an Open Access article distributed under the terms of the Creative Commons Attribution License (http://creativecommons.org/licenses/by/2.0), which permits unrestricted use, distribution, and reproduction in any medium, provided the original work is properly cited.
Received: 24 October 2007

Accepted: 2 May 2008

\begin{abstract}
Background: TRP channels have been shown to be involved in tumour generation and malignant growth. However, the expression of these channels in breast cancer remains unclear. Here we studied the expression and function of endogenous TRPC6 channels in a breast cancer cell line (MCF-7), a human breast cancer epithelial primary culture (hBCE) and in normal and tumour breast tissues.
\end{abstract}

Methods: Molecular (Western blot and RT-PCR), and immunohistochemical techniques were used to investigate TRPC6 expression. To investigate the channel activity in both MCF-7 cells and hBCE we used electrophysiological technique (whole cell patch clamp configuration).

Results: A non selective cationic current was activated by the oleoyl-2-acetyl-sn-glycerol (OAG) in both hBCE and MCF-7 cells. OAG-inward current was inhibited by 2-APB, SK\&F 96365 and $\mathrm{La}^{3+}$. TRPC6, but not TRPM7, was expressed both in hBCE and in MCF-7 cells. TRPC3 was only expressed in hBCE. Clinically, TRPC6 mRNA and protein were elevated in breast carcinoma specimens in comparison to normal breast tissue. Furthermore, we found that the overexpression of TRPC6 protein levels were not correlated with tumour grades, estrogen receptor expression or lymph node positive tumours.

Conclusion: Our results indicate that TRPC6 channels are strongly expressed and functional in breast cancer epithelial cells. Moreover, the overexpression of these channels appears without any correlation with tumour grade, ER expression and lymph node metastasis. Our findings support the idea that TRPC6 may have a role in breast carcinogenesis. 


\section{Background}

Breast cancer has the highest incidence rate for cancer in women in industrialized countries. Statistically, it is estimated that one woman out of ten will develop breast cancer at some point in her life. Evidence is accumulating for the role of ion channels in the development of cancer. The most studied ion channels in breast cancer are firstly $\mathrm{K}^{+}$ channels, which are involved in proliferation, cell cycle progression and migration [1-4], and secondly $\mathrm{Na}^{+}$channels which correlate with invasion [5-7]. Apart from the role of intracellular calcium in MCF-7 apoptosis [8], little is known of $\mathrm{Ca}^{2+}$ homeostasis in breast cancer cells. The first study reported by Strobl et al., [9], suggested that $\mathrm{Ca}^{2+}$ is necessary for the cell cycle progression in breast cancer cells. Moreover, the early findings of Sergeev indicate that voltage-insensitive channels and $\mathrm{Ca}^{2+}$ endoplasmic reticulum stores are the principal pathways for $\mathrm{Ca}^{2+}$ entry in MCF-7 breast cancer cell line [8,10]. Recently, Guo et al., [11], have reported that the inhibition of a voltage-independent calcium channel induced growth inhibition and apoptosis in breast cancer cells. However, until now, the channel types involved in this cationic current have remained unknown. Recent findings demonstrate that the expression and/or activity of the TRP superfamily, have been reported to be involved in colorectal, colon, thyroid, breast, ovarian, pancreatic and prostate cancer [12,13]. Among these, prostate cancer has been the most studied [12,14-17]. Indeed, TRPV6 is strongly expressed in advanced prostate cancer, with no expression either in healthy or in benign prostate tissues [17]. Moreover, the TRPV6 expression correlates with the Gleason score [18], and with aggressiveness $[14,16,18]$. Another type of TRP: TRPM8 was detected at high levels in both benign prostate hyperplasia and in prostate carcinoma cells, as well as at low levels in normal (non-carcinoma) prostate epithelial cells. According to these data, TRPM8 has recently been proposed as a molecular target $[13,19]$ and TRPV6 as a general marker for neoplasma $[15,20]$.

The TRPC subfamily, TRPC1 TRPC7, has mostly been implicated in regulation by G-proteins and metabolites of phosphoinositide hydrolysis. TRPC6 channels, known to be activated by the phospholipase C (PLC) product, Diacylglycerol (DAG) [21-24], is abundantly expressed and plays an important role in lung tissues and in different smooth muscle cell types [22,25-27].

TRPC6 was suggested as being the molecular correlate to the $\alpha 1$-adrenoceptor-activated non-selective cation channel in vascular smooth muscle cells [24,28]. Moreover, TRPC6 is also involved in some smooth and cardiac muscle pathologies $[27,29,30]$. TRPC6 is also expressed in epithelial human prostatic cancer cells and the $\mathrm{Ca}^{2+}$-entry via this channel mediates the activation of calcineurin, which in turn induces proliferation via its downstream NFAT (nuclear factor of activated T-cells) transcription factors, which are necessary and sufficient for the induction of prostatic cancer cell proliferation [31].

Previously, we have reported that TRPC6 is expressed in MCF-7 [32]. However, until now, little is known about the relative expression of TRPC6 in normal and cancerous breast cells.

The aim of this study is, on the one hand, to compare the expression of TRPC6 in normal and cancerous human breast tissues. On the other hand, we have sought to investigate the role of TRPC6 by using electrophysiological and molecular techniques. To do this, we used breast tissue specimens, primary cultures of human breast cancer epithelial (hBCE) cells and MCF-7 cell line.

\section{Methods \\ Cell culture}

MCF-7 cells were cultured in Eagle's Minimum Essential Medium (EMEM), supplemented with 5\% foetal calf serum (FCS), 2 mM L-glutamine, and $0.06 \%$ Hepes buffer, and maintained at $37^{\circ} \mathrm{C}$ in a humid atmosphere of $5 \% \mathrm{CO}_{2}$ in air.

\section{Immunohistochemistry}

Normal and cancerous breast tissues were obtained from fresh surgical specimens. Surgical consent forms (approved by the University Hospital of Amiens) were signed by the patients before surgery to allow the use of a portion of the tissue for research purposes.

49 normal and cancer human breast specimens were obtained from women having undergone operations at the Amiens Hospital, France. Normal breast samples were taken at a distance from the tumour. Regarding tumour grade in the 49 invasive ductal breast carcinomas, 15 were of Grade I (well-differentiated), 19 were of Grade II (moderately-differentiated) and 15 were of Grade III (poorlydifferentiated). On diagnosis, 23 tumours presented lymph-node metastasis.

Immunohistochemical studies were performed using the indirect immuno-peroxidase staining technique on the paraffin-embedded material with a Ventana ES automatic analyzer (Ventana Medical Systems) and with a hematoxylin counterstain. Briefly, after blocking the endogenous peroxidase by the I-View Inhibitor (Ventana), sections were stained with an anti-TRPC6 antibody (Chemicon, 1/ 300) for $32 \mathrm{~min}$, washed, incubated with biotinylated anti-rabbit IgG (I-View Biotin Ig, Ventana) for $8 \mathrm{~min}$, washed and exposed to streptavidine-peroxidase complex (I-View SA-HRP, Ventana) for $8 \mathrm{~min}$. DAB/H2O2 was used as chromogen and the slides were then examined under optical microscopy. Micrograph acquisitions were 
performed by a camera connected to a Zeiss microscope equipped with $20 \times 0.85$ objective lens.

Immunostaining levels in the tumour tissue were determined by subjective visual scoring of the brown stain, and compared to the normal tissue. Scoring levels were: $0=$ absence of staining; 1 = weak staining intensity (equal to normal tissue); 2 = moderate; 3 = strong staining intensity. For the quantitative analysis, we report the percentage of cases presenting an overexpression of TRPC6 (scores 2 and 3 ).

Peptide blocking was performed as follows. The TRPC6 peptide ( $1 \mu \mathrm{g}$, Chemicon) was incubated with the primary antibody $(1 \mu \mathrm{g})$ for one hour at room temperature. The complex was then applied to the sections in place of the diluted primary antibody and staining was completed as already described.

\section{Primary culture}

Portions of human breast cancerous tissues were placed in transport medium and desegregated immediately or after storage at $4{ }^{\circ} \mathrm{C}$ for less than $6 \mathrm{~h}$. The transport medium contained RPMI 1640 medium, $100 \mathrm{U} / \mathrm{ml}$ penicillin, 0.1 $\mathrm{mg} / \mathrm{ml}$ streptomycin, $2 \mathrm{mM}$ glutamine, 10\% FBS and $0.010 \mathrm{mg} / \mathrm{ml}$ insulin. Adipose or gross and necrotic materials were removed and the tissue minced using a scalpel in phosphate buffer solution (PBS) pH 7.4 under sterile conditions. Cancerous tissues were digested in transport medium containing $1 \mathrm{mg} / \mathrm{ml}$ collagenase type I (Sigma, France) and $100 \mathrm{U} / \mathrm{ml}$ hyaluronidase (Sigma, France) overnight at $37^{\circ} \mathrm{C}$. When digestion was completed, tissue suspensions were centrifuged at $1000 \mathrm{rpm}$ for $5 \mathrm{~min}$ and the pellets resuspended in sterile PBS pH 7.4. The dispersed cell suspensions were centrifuged at $1000 \mathrm{rpm}$ for 5 min and pellets resuspended in 20\% FBS growth medium (RPMI 1640 medium, $100 \mathrm{U} / \mathrm{ml}$ penicillin, 0.1 $\mathrm{mg} / \mathrm{ml}$ streptomycin, $2 \mathrm{mM}$ glutamine, $0.005 \mathrm{mg} / \mathrm{ml}$ insulin, $5 \mathrm{ng} / \mathrm{ml}$ epidermal growth factor (EGF), $0.5 \mu \mathrm{g} /$ $\mathrm{ml}$ hydrocortisone, $5 \mu \mathrm{g} / \mathrm{ml}$ transferrin, $0.1 \mu \mathrm{M}$ isoproterenol, $0.01 \mu \mathrm{M}$ ethanolamine, $0.01 \mu \mathrm{M}$ o-phosphoetanolamine) and seeded in culture flasks (Nunc, Poly Labo, Strasbourg, France) and kept at $37^{\circ} \mathrm{C}$ in a humidified incubator in a 95\% air 5\% CO2 atmosphere. Each sample was analyzed by immuno-fluorescence staining to verify the pan-cytokeratin expression, which is an epithelial marker.

We used specimens from invasive ductal breast carcinomas and clinical tumour (Grade II), from patients having undergone a mastectomy. None of the patients had a history of chemotherapy and/or anti-estrogens therapy. The absence of normal epithelial cells was confirmed by independent histologic and anatomopathologic analysis.

\section{Electrophysiology}

For electrophysiological analysis, cells were cultured in 35 $\mathrm{mm}$ Petri dishes at a density of $5.10^{4}$ cells 2 days before patch clamp experiments. Currents were recorded in voltage-clamp mode, using an Axopatch 200 B patch-clamp amplifier (Molecular devices) and a Digidata 1200 interface (Molecular device). PClamp software (v. 6.03, Molecular device) was used to control voltage, as well as to acquire and analyze data. The whole-cell mode of the patch-clamp technique was used with 3-5 $\mathrm{M} \Omega$ resistance borosilicate fire-polished pipettes (Hirschmann ${ }^{\circledR}$, Laborgerate). Seal resistance was typically in the 1-5 G $\Omega$ range. Whole cell currents were allowed to stabilize for 5 min before being measured. Cells were allowed to settle in Petri dishes placed at the opening of a $250 \mu \mathrm{m}$-inner diameter capillary for extra-cellular perfusions. The cell under investigation was continuously superfused with control or test solutions. All electrophysiological experiments were performed at room temperature.

\section{Total RNA isolation and reverse transcription of RNA}

Total RNA from MCF-7 cells and primary culture cells was extracted by the Trizol-phenol-chloroforme (Sigma Aldrich) procedure, including DNAse I treatment (0.2 U/ $\mu \mathrm{l}, 30 \mathrm{~min}$ at $37^{\circ} \mathrm{C}$, Promega). Total RNA was then reverse-transcribed into cDNA using oligodT primers and SuperScript ${ }^{\mathrm{TM}}$ II Reverse Transcriptase (Invitrogen).

RNA isolation of normal and tumour tissues was performed using the RNAeasy Mini Kit (Qiagen). Pieces of tissue $(20 \mathrm{mg}$ ) were placed in a lysis buffer and homogenized using a Polytron homogenizer (PRO-200, Fisher Bioblock Scientific), and total RNA was isolated according to the manufacturer s standard protocols and used ( $1 \mu \mathrm{g})$ for first-strand cDNA synthesis with oligodT primers and MultiScribeTM Reverse Transcriptase (Applied Biosystems).

\section{Qualitative and semi-quantitative PCR}

Sense and antisense PCR primers specific to TRPC3, TRPC6, TRPC7 channels, $\beta$-actin and cytokeratin 19 (CK19) were used (see Table 1: primers for PCR experiments). PCR reactions were carried out on a iCycler thermal cycler (Biorad) using Taq DNA polymerase (Invitrogen) using the following parameters: denaturation at $94^{\circ} \mathrm{C}$ for $30 \mathrm{~s}$, annealing at $58^{\circ} \mathrm{C}$ for $30 \mathrm{~s}$, and extension at $72^{\circ} \mathrm{C}$ for $40 \mathrm{~s}$. A total of 30 cycles for actin and 40 cycles for the other primers were performed, followed by a final extension at $72^{\circ} \mathrm{C}$ for $5 \mathrm{~min}$. PCR products were analyzed by electrophoresis with $1.5 \%$ agarose gel and visualized by ethidium bromide staining.

For the semi-quantitative experiments, 40 cycles, 25 cycles and 35 cycles were performed for TRPC6, $\beta$-actin and CK19 respectively. After agarose gel electrophoresis, PCR 
Table I: Primers for PCR experiments

\begin{tabular}{|c|c|c|c|c|}
\hline Gene & Accession $n^{\circ}$ & Primer & Sequence (5-3) & Predicted Size, bp \\
\hline \multirow[t]{2}{*}{ hTRPC3 } & NM003305 & Sense & GGAAAAACATTACCTCCACCTTTCA & \\
\hline & & Antisense & CTCAGTTGCTTGGCTCTTGTCTTCC & $383 \mathrm{pb}$ \\
\hline \multirow[t]{2}{*}{ hTRPC6 } & NM 004621 & Sense & GAACTTAGCAATGAACTGGCAGT & $625 \mathrm{pb}$ for TRPC6 \\
\hline & & Antisense & CATATCATGCCTATTACCCAGGA & $277 \mathrm{pb}$ for TRPC6 $\gamma$ \\
\hline \multirow[t]{2}{*}{ hTRPC7 } & NM 020389 & Sense & GTCCGAATGCAAGGAAATCT & \\
\hline & & Antisense & TGGGTTGTATTTGGCACCTC & $477 \mathrm{pb}$ \\
\hline \multirow[t]{2}{*}{$\mathrm{h} \beta$-actin } & NM 001101 & Sense & CAGAGCAAGAGAGGCATCCT & \\
\hline & & Antisense & ACGTACATGGCTGGGGTG & $210 \mathrm{pb}$ \\
\hline \multirow[t]{2}{*}{ hCKI9 } & NM 002276 & Sense & GATTGCCACCTACCGC & \\
\hline & & Antisense & ССАТСССТСТАСССAG & $136 \mathrm{pb}$ \\
\hline
\end{tabular}

products were quantified using Quantity One software (Biorad) and expressed as the ratio of TRPC6 on $\beta$-actin or CK19 referent genes. CK19 has been shown to be specific to breast epithelial cells, both normal and malignant [33].

\section{Western Blotting}

Prostate human cancer cell line (LNCaP), MCF-7 cells and primary culture cells were lysed for $30 \mathrm{~min}$ on ice in RIPA buffer $(1 \%$ triton $\times 100,1 \%$ Na deoxycholate, $150 \mathrm{mM}$ $\mathrm{NaCl}, 10 \mathrm{mM} \mathrm{PO} 4 \mathrm{Na}_{2} / \mathrm{K} \mathrm{pH}$ 7.2) supplemented with Sigma P8340 inhibitor cocktail, $2 \mathrm{mM}$ EDTA and $5 \mathrm{mM}$ Na orthovanadate. After centrifugation at $13000 \mathrm{rpm}$, the proteins in the supernatant were quantified using the BCA method (Biorad).

Breast tissue proteins were extracted using the WCE buffer (Whole Cell Extract : $150 \mathrm{mM} \mathrm{NaCl}, 50 \mathrm{mM}$ Tris $\mathrm{HCl}$ pH7.5, 1\% NP40) supplemented with Sigma P8340 inhibitors cocktail, $0.1 \%$ SDS and $1 \mathrm{mM} \mathrm{Na}$ orthovanadate. After 1 hour in lysis buffer at $4{ }^{\circ} \mathrm{C}$, tissues were homogenized using a Polytron homogenizer (PRO-200, Fisher Bioblock Scientific) and frozen $20 \mathrm{~min}$ at $-80^{\circ} \mathrm{C}$. After centrifugation at $13000 \mathrm{rpm}$, the proteins in the supernatant were quantified using the BCA method (Biorad).

Equal amounts of each protein sample (15-20 $\mu \mathrm{g})$ were separated by electrophoresis on SDS-PAGE and blotted onto nitrocellulose membrane (Amersham). Blots were incubated with antibodies raised against TRPC6 (1/300, Chemicon) or $\beta$-actin (1/1000, Santa Cruz) and developed with the enhanced chemiluminescence system (ECL, Amersham) using specific peroxidase-conjugated anti-IgG secondary antibodies. Peptide blocking was performed as described in the immunohistochemistry section.

\section{Solutions}

External and internal solutions had the following compositions (in $\mathrm{mM}$ ): External: $\mathrm{NaCl} 140, \mathrm{KCl} 5, \mathrm{MgCl}_{2} 2$, $\mathrm{CaCl}_{2} 2$, HEPES 10 and glucose 5 at $\mathrm{pH} 7.4(\mathrm{NaOH})$. Internal: $\mathrm{CsCl} 140, \mathrm{CaCl}_{2}$ 5, ATP-K $\mathrm{K}_{2}$, HEPES 10, EGTA
$10, \mathrm{MgCl}_{2} 2$, at $\mathrm{pH} 7.2(\mathrm{CsOH})$. The [ $\left.\mathrm{Ca}^{2+}\right] \mathrm{i}$ was clamped to $85 \mathrm{nM}$ and calculated with WebMaxC v2.1 (please see Availability \& requirements section below).

Extracellular and intracellular osmolarity measured with a freezing-point depression were $300 \mathrm{mOs}$ and $292 \mathrm{mOs}$ respectively. In order to completely block $\mathrm{K}^{+}$channels, we added TEA at $5 \mathrm{mM}$ to the extracellular medium. 2-APB, SK\&F 96365 and OAG (Sigma, France) were dissolved in DMSO. Final concentrations were obtained by appropriate dilution in an external control solution. The final DMSO concentration was $<0.1 \%$.

\section{Statistical analysis}

Results were expressed as mean \pm S.E. The Student $s$ t test was used to compare the relative TRPC 6 transcripts in normal and cancer tissues. $\mathrm{P}<0.05$ was considered as significant. Immunostaining in the epithelial compartment of tumour tissues compared to normal tissues was scored visually as equal expression or overexpression of TRPC6. $\chi^{2}$ tests were used in GraphPad Software to estimate the correlation between TRPC6 overexpression and clinical characteristics of the carcinoma tissues. A correlation was considered significant when $\mathrm{P}<0.05$.

\section{Results}

OAG induced a non-selective cationic current in the MCF7 breast cell line

We have previously reported that TRPC6 is the detectable member of the store-independent TRPC channels expressed in breast cancer cells [32]. Recent studies have revealed that the permeant DAG analogue, OAG can stimulate an inward current in cancerous epithelial cells [31]. We recorded OAG-induced channel activity in MCF-7 cells using the whole cell patch clamp configuration, replacing $\mathrm{K}^{+}$with $\mathrm{Cs}^{+}$to block $\mathrm{K}^{+}$channels and using a high $\left[\mathrm{Ca}^{2+}\right]$ i to prevent the passive intracellular $\mathrm{Ca}^{2+}$ store depletion that could lead to activation of store operated channels (SOC, $\mathrm{I}_{\text {soc }}$ current) (Fig. 1). An application of 50 $\mu \mathrm{M}$ of OAG to the bath induced a linear current in MCF-7 cells. The current/voltage dependence of this OAG- 

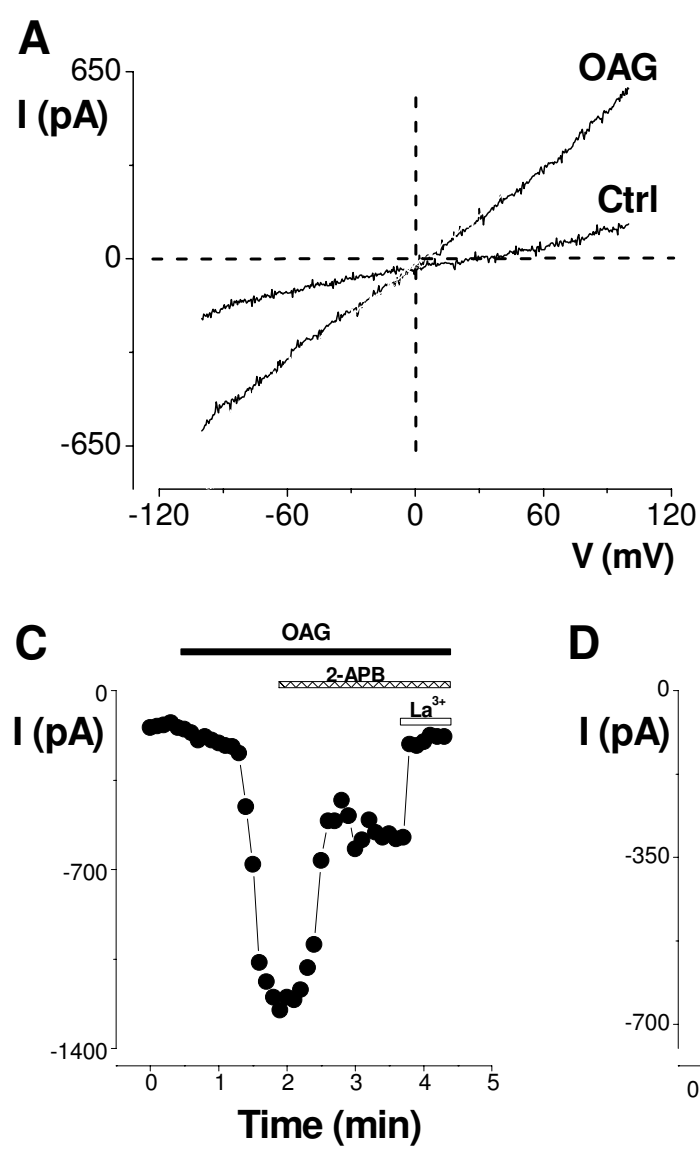

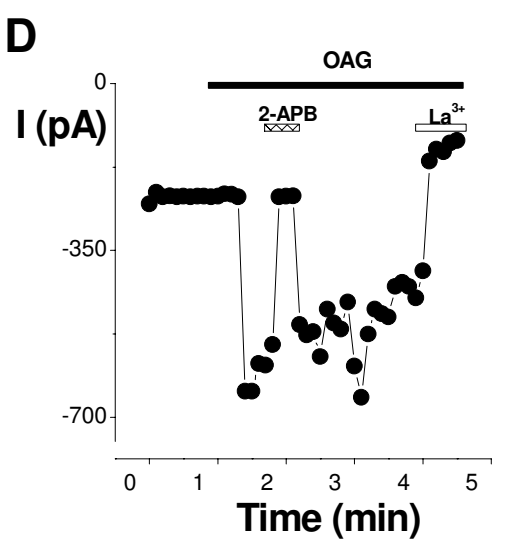

\section{Figure I}

Electrophysiological and Pharmacological characterisation of the OAG-induced current in MCF-7 cell line. A) Typical current trace recorded during the current induced by $50 \mu \mathrm{M}$ OAG. The holding potential was $-40 \mathrm{mV}$ and $400 \mathrm{~ms}$ voltage ramps were applied from $-100 \mathrm{mV}$ to $+100 \mathrm{mV}$. The reversal potential $\left(\mathrm{E}_{\text {rev }}\right)$ of the currents recorded was about $0 \mathrm{mV}$. B) Time course development of OAG-inward currents (measured at $-100 \mathrm{mV}$ ) in a representative $\mathrm{MCF}-7$ cell bathed in external control medium. C-D) 2-APB (50 and $100 \mu \mathrm{M})$ and $\mathrm{La}^{3+}(100 \mu \mathrm{M})$ effects on time course of OAG-induced current recorded at - I00 mV. E) The extracellular perfusion of SK\&F 96365 (I0 $\mu \mathrm{M})$ completely inhibited the current induced by OAG (50 $\mu \mathrm{M})$.

induced current displayed both inward and outward currents (Fig. 1A). This current revealed a pattern of a nonselective cation current (Fig. 1A) with a reversal potential close to $0 \mathrm{mV}(7.2 \pm 1.4, \mathrm{n}=12)$. The average density of OAG-induced current measured at $-100 \mathrm{mV}$ varied between -25 and $-12.5 \mathrm{pA} / \mathrm{pF}$ with a mean of $-18.3 \pm 2.7$ $\mathrm{pA} / \mathrm{pF}(\mathrm{n}=10)$. The time course for OAG-induced current at $-100 \mathrm{mV}$ revealed an inward current which reached a peak in about 3 min (Fig. 1B).

\section{Pharmacological properties of the OAG-induced current}

A number of pharmacological agents have been used to characterize DAG-induced currents or $\mathrm{Ca}^{2+}$ entry pathways in a variety of cell types [34]. Here we show that 2APB reduced and completely inhibited the OAG-induced current in MCF-7 cells when used at $50 \mu \mathrm{M}$ and $100 \mu \mathrm{M}$ respectively (Fig. $1 C D, n=4$ ), and this effect was totally reversed after washout (Fig. 1D). Moreover, the OAG-sensitive current was also completely inhibited by $100 \mu \mathrm{M}$ $\mathrm{La}^{3+}$ (Fig. 1CD, $\mathrm{n}=6$ ) and by $10 \mu \mathrm{M}$ SK\&F 96365 (Fig. 1E, $\mathrm{n}=3)$.

\section{OAG also induced a cationic current in primary epithelial breast human cells (hBCE)}

A typical OAG-induced current could also be recorded in hBCE cells. A representative example is shown in Fig. 2AB. The average density of the OAG-induced current measured at $-100 \mathrm{mV}$ varied between -50 and $-20.6 \mathrm{pA} / \mathrm{pF}$ with a mean of $-34.3 \pm 4.6 \mathrm{pA} / \mathrm{pF}(\mathrm{n}=7)$. The current that we recorded had a $\mathrm{E}_{\text {rev }}$ about $0 \mathrm{mV}(6.0 \pm 2.4 \mathrm{mV},(\mathrm{n}=4))$ and 

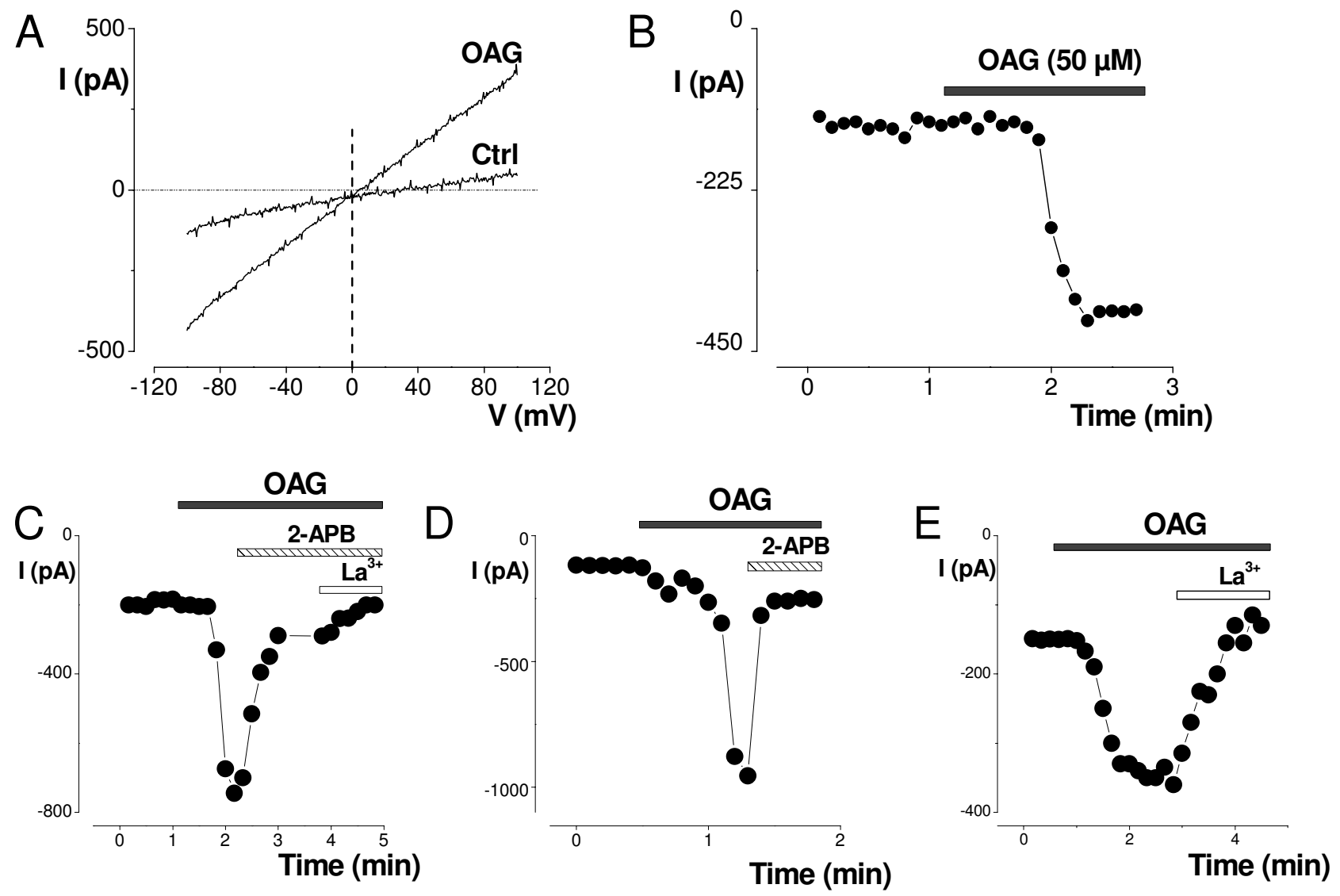

Figure 2

OAG mediated an inward cationic current in primary hBCE. A) Current-potential relationship in the absence and presenceof OAG $(50 \mu \mathrm{M})$. The holding potential was $-40 \mathrm{mV}$ and $400 \mathrm{~ms}$ voltage ramps were applied from - I00 mV to +100 $\mathrm{mV}$. B) Time course of the inward whole-cell membrane current activated by OAG (50 $\mu \mathrm{M})$. C-E) Effects of the common cationic channels inhibitors, 2-APB $50 \mu \mathrm{M}(\mathrm{C}), 100 \mu \mathrm{M}(\mathrm{D})$, and $100 \mu \mathrm{M} \mathrm{La}{ }^{3+}(\mathrm{C}, \mathrm{E})$ on the amplitude of OAG-induced inward current measured at $-100 \mathrm{mV}$.

was again reduced by $50 \mu \mathrm{M} 2$-APB (Fig. 2C, $\mathrm{n}=6$ ) or completely blocked by $100 \mu \mathrm{M} 2$-APB (Fig. 2D, $\mathrm{n}=6$ ) and by $\mathrm{La}^{3+}(100 \mu \mathrm{M}, \mathrm{n}=6)$ (Fig. 2CE).

\section{Expression of OAG-gated TRP channels in human breast cancer epithelial cells}

TRPC3, TRPC6 and TRPC7 are reported to be directly gated by DAG and OAG $[23,35]$. Therefore, in order to determine potential candidates for the OAG-coupled cationic channel(s) in hBCE, we used RT-PCR to analyse the expression of the specific transcripts for the human isoforms of these DAG-gated TRP members in these cells. As expected, MCF-7 cells expressed only TRPC6 while hBCE expressed both TRPC6 and TRPC3 transcripts (Fig. 3A), whereas TRPC7 was undetectable (Fig. 3B) in either cell. The prostate cancer cell line ( $\mathrm{LNCaP}$ ) was used as a positive control for TRPC3 and a negative one for TRPC6.
Indeed, it has been reported that $\mathrm{LNCaP}$ cells express TRPC3 but not TRPC6 [36]. Moreover, both MCF-7 and hBCE cells express a TRPC6 $\gamma$ splice variant (Fig. 3A).

\section{TRPC6 is expressed in breast tumour tissues}

No data are available on the expression of TRPC6 in human carcinoma tissue. Fig. 4 shows the expression of the transcripts for the TRPC6 in human breast tissue (Fig. $4 \mathrm{~A})$. Moreover, we also observed the expression of the TRPC6 $\gamma$ splice variant. Using Western blotting, we found that the TRPC6 proteins were expressed in breast carcinoma (Fig. 4B). There was no band when we omitted the primary antibody or when we blocked the TRPC6 antibody with the TRPC6 peptide (Fig. 4B). Moreover, TRPC6 is also expressed at a protein level both in MCF-7 cells and in hBCE (Fig. 4C). Again, there was no band when we used lysate from LNCaP (Fig. 4C). 
A

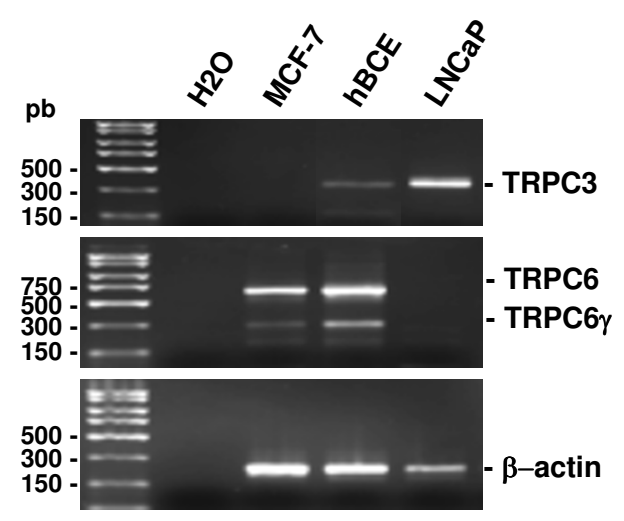

B

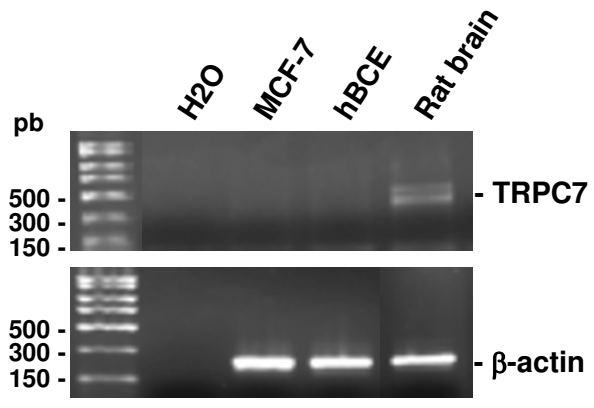

Figure 3

Analysis of TRPC3, TRPC6 and TRPC7 mRNA expression in MCF-7 and $h B C E$ cells. RT-PCR analysis of the expression of human TRPC3, TRPC6 (A), and TRPC7 (B) transcripts in hBCE and MCF-7 cells. The PCR products were obtained using the primers described in Table I. Rat brain and the human prostate cancer epithelial cell line (LNCaP) were used as positive controls for the detection of TRPC7, and TRPC3 respectively. LNCaP was also used as negative control for TRPC6.

\section{Overexpression of TRPC6 in breast adenocarcinoma}

Immunohistochemical analysis was performed on 49 normal tissues and ductal breast carcinomas. Normal breast specimens were obtained from mammectomy specimens, at a distance from the tumour. High expression of TRPC6 was detected in tissue of breast cancer and small or negative expression was detected in normal tissue. The frequency of TRPC6 expression in breast cancer averaged $73.4 \%(36 / 49)$ of the cases studied. Fig. 5A shows representative positive expression of neoplastic tissue of breast cancer. The staining of breast adenocarcinoma (a2) demonstrated a stronger positive reaction than its normal counterpart (a1). There was no or little staining when the primary antibody was omitted (b1, b2), or after preincubation of TRPC6 peptide with the primary antibody (c1, c2).
Using semi-quantitative PCR, we analyzed TRPC6 mRNA expression in tumour and normal tissues from 3 individual patients. As shown in Fig. 5B \&5C, TRPC6 mRNA expression was generally higher in the tumour tissues after normalization both with CK19 or $\beta$-actin $(\mathrm{P}<0.05)$.

We next compared the expression of TRPC6 with LNM, estrogen receptor (ER) expression, and tumour grade. A quantitative analysis, using $\chi^{2}$ statistical test, of the results obtained is reported in Table 2. The TRPC6 protein expression was similar in tumour tissues associated $(78 \%$, $\mathrm{n}=23$ ) or not associated $(69 \%, \mathrm{n}=26)$ with LNM. Non significant differences in the TRPC6 expression were also found with estrogen receptor expression. Regarding TRPC6 channel protein expression with tumour grade, we found that TRPC6 was expressed in $73.3 \%$ and $68.4 \%$ of grade I and grade II respectively, and increased to $80 \%$ in grade III.

\section{Discussion}

Many recent works report the involvement of TRP channels in cancer. Our results point towards an aberrant expression of TRPC6 channels in breast cancer. This study shows that TRPC6 is expressed in both the MCF-7 breast cancer cell line and in the primary cultures of breast cancer epithelial cells. TRPC6 appears to be functional both in MCF-7 and in hBCE. Moreover, TRPC6 is highly expressed in breast carcinoma and is not correlated with estrogen receptor expression, tumour grade, or LNM.

Our results demonstrate that the OAG-activated cationic channels both in hBCE and MCF-7 cells share the same electrophysiological (lack of voltage dependence, and a similar reversal potential) and pharmacological properties (sensitivity to 2-APB, $\mathrm{La}^{3+}$ and $\mathrm{SK} \& \mathrm{~F}$ 96365). The TRPC candidates activated by OAG are limited to TRPC3, TRPC6, and TRPC7 [23,35]. TRPC6 is expressed at mRNA and protein levels both in MCF-7 and hBCE cells. Moreover, TRPC3 is also expressed in hBCE and its expression seems weak compared to that of the TRPC6 (Fig. 3A). However, the findings that hBCE cells express both TRPC3 and TRPC6, may indicate that the OAG-gated cationic channel(s) in theses cells are probably heterotetramultimers that include TRPC6/TRPC3.

We also extended our studies to examine TRPC6 expression at the protein levels in breast cancer tissues. No specific bands were obtained when we performed Western blot analyses: (i) on lysates from LNCaP, used as negative control [36], (ii) by omitting the primary antibody and (iii) by blocking the primary antibody with the TRPC6 peptide. In contrast, both tumour, MCF-7 and hBCE lysates produced a $97 \mathrm{kDa}$ band corresponding to the expected size of full length TRPC6. Moreover, no other 


\section{A}

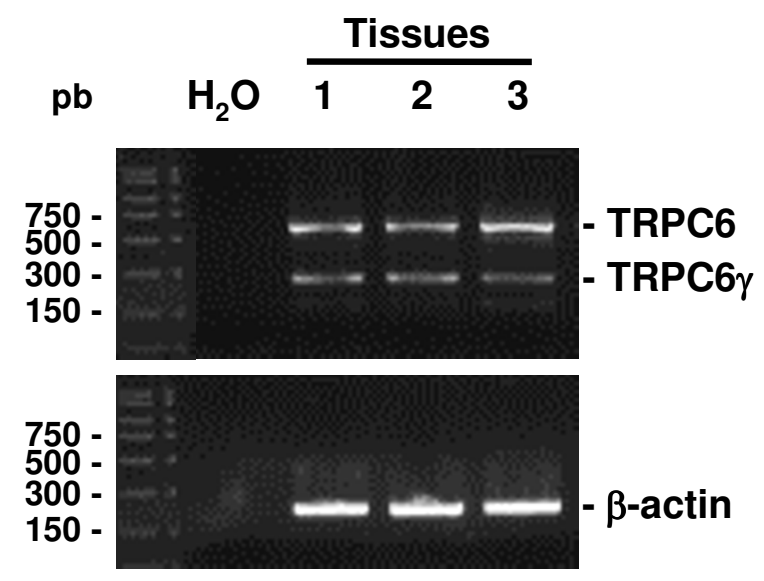

B
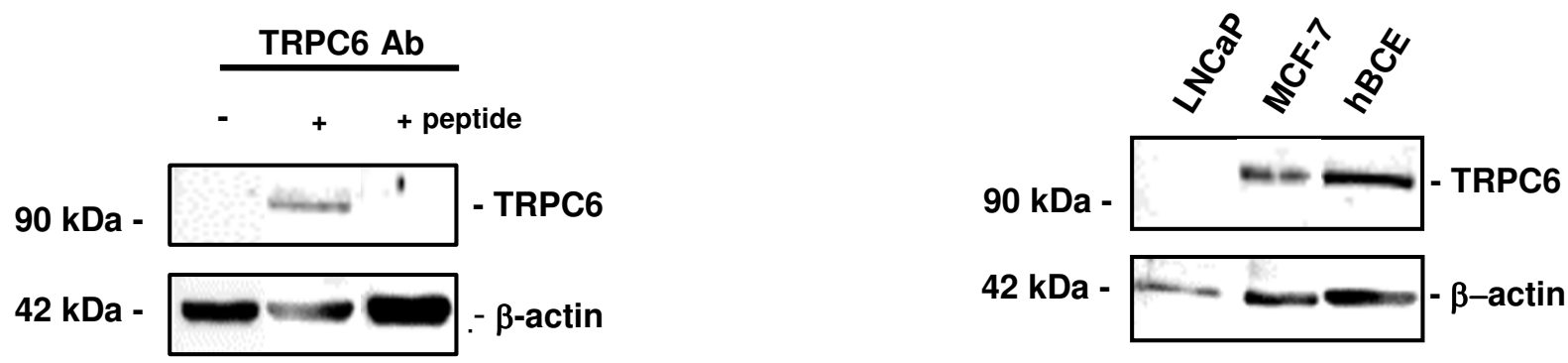

Figure 4

Expression of TRPC6 in human breast cancer. A) Expression pattern of TRPC6 mRNA. The PCR products were observed in 3 human tumour breast tissues. A representative Western blot of TRPC6 (around $97 \mathrm{kDa}$ ) was performed on breast tumour tissues (B), MCF-7 and hBCE cells (C). TRPC6 Ab : TRPC6 antibody; (-) incubation of tumour tissue protein lysates with only the second antibody; (+ peptide) protein lysates are incubated with a mixture of TRPC 6 antibody and TRPC6 peptide. Protein lysates from LNCaP cells were used as negative control (C).

band was observed, suggesting that TRPC6 $\gamma$ splice variant is not translated into protein.

A growing number of studies demonstrate a close correlation between an overexpression of TRP channels particularly of the TRPV6 and TRPM 8 families and the development of cancer $[13,16]$. However, little is known about the expression pattern of TRPC6 or its possible role in the development of cancer, and breast cancer in particular. To our knowledge, there is only one study which shows the involvement of the TRPC6 channels in the pro- liferation of epithelial human prostate cancer cells in primary culture [31]. Our results clearly show that in healthy breast tissues low levels of TRPC6 are detected in all cases determined. In contrast, the breast carcinoma tissue specimens revealed a significant overexpression of TRPC6. Moreover, TRPC6 are expressed and functional in the MCF-7 cell line and in hBCE. In vivo, the upregulation of TRPC6 was much more clearly demonstrated in cardiovascular pathologies such as hypertension, hypertrophy and increased endothelial permeability $[27,29,30]$. 
A
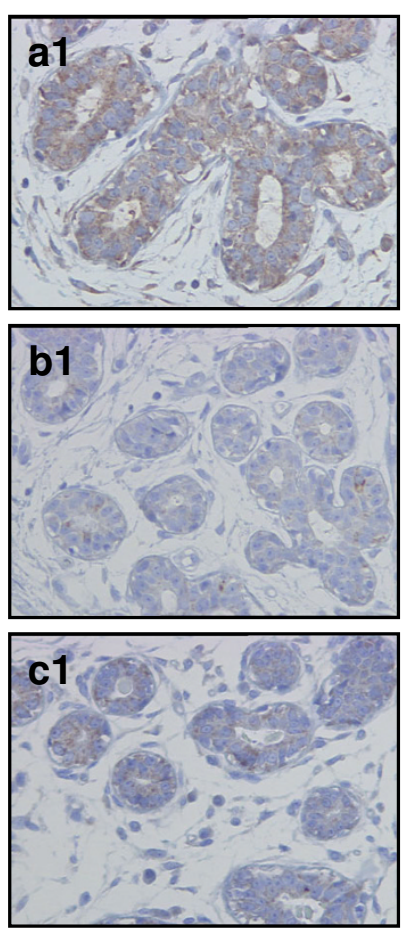
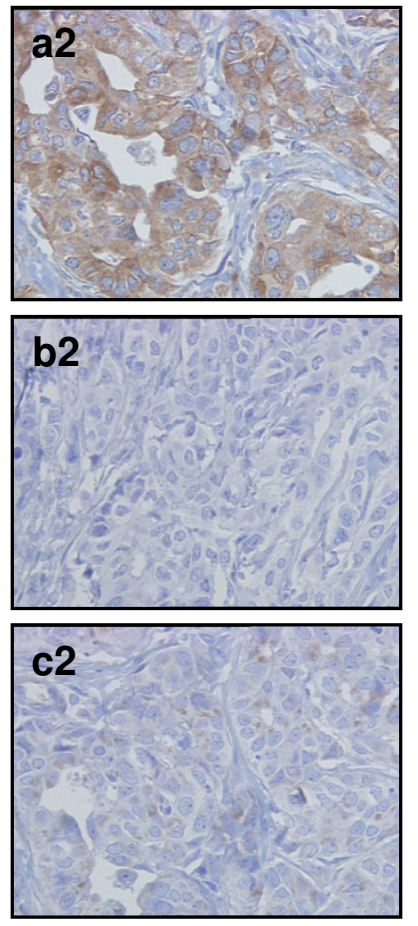

B

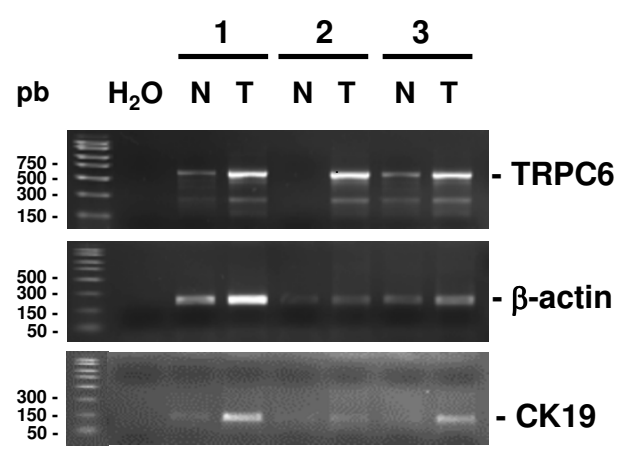

C

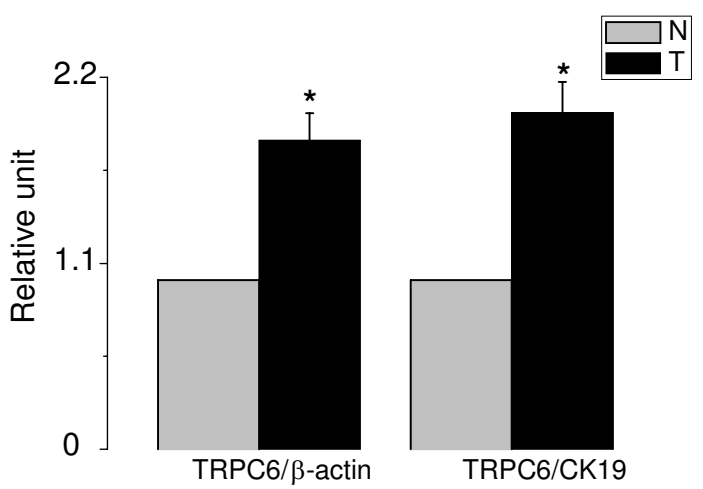

\section{Figure 5}

Overexpression of TRPC 6 in breast adenocarcinoma. A) Normal (al) and tumour (a2) breast tissues show a respectively weaker and a stronger staining when incubated with TRPC6 antibody. (bl) and (b2) are the same field showing no staining when the primary antibody was omitted. TRPC 6 staining of normal $(\mathrm{cl})$ and tumour $(\mathrm{c} 2)$ breast tissue was blocked by the preincubation of TRPC6 peptide with the primary antibody. (magnification, $\times 200$ ). B) TRPC6 transcripts were detected in breast tissues ( $N=$ normal, $T$ = tumour) by semi-quantitative PCR using TRPC6, $\beta$-actin, or CK 19 primers. $C$ ) Relative TRPC6 expression in breast cancer tissues. TRPC6 mRNA was quantified using Quantity One software and normalized to $\beta$-actin or CK 19 expression. Data are presented as the average of duplicate experiments on three distinct patients $(* P<0.05)$.

Few studies have compared the ionic channel expression with the tumour grade, LNM and receptor expression status. Indeed, GIRK1 was overexpressed in primary invasive breast carcinoma and correlate with LNM [37]. Pardo s group has found there were no correlations between Eag1 expression and age, grade and site of tumour of soft tissue sarcoma [38]. Similar results on Eag1 expression are found in colorectal cancer [39]. In line with these studies, we show that the TRPC6 protein levels are increased in breast tumour tissues but were not correlated either with tumour grade, ER or LNM.

Evidence indicates a crucial role for TRP channels in regulating both cell growth and cell death. Recently, it was reported that TRPV6 induced cell proliferation and took part in the resistance to apoptosis in the prostate human LNCaP cancer cells [40]. TRPC6 has been reported to be involved in primary epithelial prostate human cell proliferation induced by the $\alpha_{1}$-adrenergic receptors [31]. Breast cancer cells, including MCF-7 express G proteincoupled receptors including $\alpha 1$-adrenergic receptors [41]. We can thus speculate that the entry of $\mathrm{Ca}^{2+}$ through TRPC6 channel may induce breast cancer cell proliferation in response to $\mathrm{G}$ protein-coupled receptor signalling. More studies are needed to determine the involvement of TRPC6 in breast cell proliferation.

\section{Conclusion}

Our data demonstrate that TRPC6 is expressed and functional in breast cancer epithelial cells. Moreover, this 
Table 2: Comparison of TRPC6 expression to tumour characteristics on 49 patients using $\chi 2$ analysis.

\begin{tabular}{lccc}
\hline & TRPC6 overexpression & $n$ & $X^{2}$ \\
\hline LNM status & & & \\
$\quad$ LNM & $78.3 \%$ & 23 & \\
no LNM & $69.2 \%$ & 26 & 0.4749 \\
ER status & & & \\
ER+ & $70.9 \%$ & 31 & \\
$\quad$ ER- & $81.8 \%$ & 11 & 0.5180 \\
Tumor grade & & & \\
I & $73.3 \%$ & 15 & \\
2 & $68.4 \%$ & 19 & 0.4473 \\
3 & $80 \%$ & 15 & 0.4473 \\
\hline
\end{tabular}

Absence of significant statistical correlation between TRPC6 overexpression and tumour characteristics (LNM: lymph node metastasis; ER: estrogen receptor).

channel is overexpressed in tumour tissues without any correlation with tumour grade, ER expression and lymph node metastasis.

\section{Competing interests}

The authors declare that they have no competing interests.

\section{Availability \& requirements}

WebMaxC v2.1: http://www.stanford.edu/ cpatton/ webmaxc2.htm

\section{Authors' contributions}

AG and YELH did the electrophysiological studies and MCF-7 cell culture. ID-D did the immunohistochemistry, the conventional PCR studies, and carried out the TRPC6 Western blots. NH and HK carried out the RNA extraction of the primary culture, cell line (MCF-7) and biopsy specimens. AA did the primary epithelial culture and corrected the manuscript. HS provided us with the human biopsies and allowed us to do the IHC in his laboratory. HO-A designed the studies and wrote the manuscript. All authors have read and approved the final manuscript

\section{Acknowledgements}

Financial support for the research described in this article was provided by the Région Picardie, Cancéropôle Nord-Ouest (INCa), Ligue contre le Cancer, the Ministère de I Education Nationale and ARC (Association pour la Recherche sur le Cancer). We thank Jean François Lefebvre for his excellent technical assistance as well as staff at the Amiens hospital.

\section{References}

I. Wonderlin WF, Strobl JS: Potassium channels, proliferation and GI progression. J Membr Biol 1996, I54(2):91-107.

2. Ouadid-Ahidouch H, Le Bourhis X, Roudbaraki M, Toillon RA, Delcourt $\mathrm{P}$, Prevarskaya $\mathrm{N}$ : Changes in the $\mathrm{K}^{+}$current-density of MCF-7 cells during progression through the cell cycle: possible involvement of a h-ether.a-gogo $\mathbf{K}^{+}$channel. Receptors Channels 200I, 7(5):345-356.

3. Ouadid-Ahidouch $\mathrm{H}$, Roudbaraki M, Delcourt P, Ahidouch A, Joury $\mathrm{N}$, Prevarskaya $\mathrm{N}$ : Functional and molecular identification of intermediate-conductance $\mathrm{Ca}^{(2+)}$-activated $\mathrm{K}^{(+)}$channels in breast cancer cells: association with cell cycle progression. Am J Physiol Cell Physiol 2004, 287(I):CI25-I34.

4. Potier M, Joulin V, Roger S, Besson P, Jourdan ML, Leguennec JY, Bougnoux $P$, Vandier C: Identification of SK3 channel as a new mediator of breast cancer cell migration. Mol Cancer Ther 2006, 5(I I):2946-2953.

5. Roger S, Besson P, Le Guennec JY: Involvement of a novel fast inward sodium current in the invasion capacity of a breast cancer cell line. Biochim Biophys Acta 2003, I616(2): I07-III.

6. Roger S, Potier M, Vandier C, Besson P, Le Guennec JY: Voltagegated sodium channels: new targets in cancer therapy? Curr Pharm Des 2006, 12(28):368I-3695.

7. Fraser SP, Diss JK, Chioni AM, Mycielska ME, Pan H, Yamaci RF, Pani F, Siwy Z, Krasowska M, Grzywna Z, et al.: Voltage-gated sodium channel expression and potentiation of human breast cancer metastasis. Clin Cancer Res 2005, I I (I5):538I-5389.

8. Sergeev IN: Calcium signaling in cancer and vitamin D. J Steroid Biochem Mol Biol 2005, 97(I-2): I45-I5I.

9. Strobl JS, Wonderlin WF, Flynn DC: Mitogenic signal transduction in human breast cancer cells. Gen Pharmacol 1995, 26(8): 1643-1649.

10. Sergeev IN, Rhoten WB: Regulation of intracellular calcium in human breast cancer cells. Endocrine 1998, 9(3):321-327.

II. Guo L, Li ZS, Wang HL, Ye CY, Zhang DC: Carboxyamido-triazole inhibits proliferation of human breast cancer cells via G(2)/M cell cycle arrest and apoptosis. Eur J Pharmacol 2006, 538(I-3): I5-22.

12. Zhuang L, Peng JB, Tou L, Takanaga H, Adam RM, Hediger MA, Freeman MR: Calcium-selective ion channel, CaTI, is apically localized in gastrointestinal tract epithelia and is aberrantly expressed in human malignancies. Lab Invest 2002, 82(12): 1755-1764.

13. Bodding $M$, Wissenbach $U$, Flockerzi V: Characterisation of TRPM8 as a pharmacophore receptor. Cell Calcium 2007, 42(6):6|8-628.

14. Fixemer T, Wissenbach U, Flockerzi $\mathrm{V}$, Bonkhoff $\mathrm{H}$ : Expression of the $\mathrm{Ca}^{2+}$-selective cation channel TRPV6 in human prostate cancer: a novel prognostic marker for tumor progression. Oncogene 2003, 22(49):7858-786।.

15. Bodding M: TRP proteins and cancer. Cell Signal 2007, 19(3):617-624.

16. Prevarskaya N, Zhang L, Barritt G: TRP channels in cancer. Biochim Biophys Acta 2007, 1772(8):937-946.

17. Wissenbach $U$, Niemeyer B, Himmerkus N, Fixemer T, Bonkhoff $H$, Flockerzi V: TRPV6 and prostate cancer: cancer growth beyond the prostate correlates with increased TRPV6 $\mathrm{Ca}^{2+}$ channel expression. Biochem Biophys Res Commun 2004, 322(4): $1359-1363$.

18. Peng JB, Zhuang L, Berger UV, Adam RM, Williams BJ, Brown EM, Hediger MA, Freeman MR: CaTI expression correlates with tumor grade in prostate cancer. Biochem Biophys Res Commun 200I, 282(3):729-734.

19. Zhang L, Barritt G]: TRPM8 in prostate cancer cells: a potential diagnostic and prognostic marker with a secretory function? Endocr Relat Cancer 2006, I3(1):27-38.

20. Wissenbach $U$, Niemeyer BA, Fixemer T, Schneidewind A, Trost $C$ Cavalie A, Reus K, Meese E, Bonkhoff H, Flockerzi V: Expression of CaT-like, a novel calcium-selective channel, correlates with the malignancy of prostate cancer. I Biol Chem 200I, 276(22): 1946|-19468.

21. Dietrich A, Gudermann T: TRPC6. Handb Exp Pharmacol 2007, I79:|25-|4|.

22. Soboloff J, Spassova M, Xu W, He LP, Cuesta N, Gill DL: Role of endogenous TRPC6 channels in $\mathrm{Ca}^{2+}$ signal generation in A7r5 smooth muscle cells. I Biol Chem 2005, 280(48):39786-39794.

23. Trebak M, Vazquez G, Bird GS, Putney JW Jr: The TRPC3/6/7 subfamily of cation channels. Cell Calcium 2003, 33(5-6):45I-46I.

24. Inoue R, Okada T, Onoue H, Hara Y, Shimizu S, Naitoh S, Ito Y, Mori $Y$ : The transient receptor potential protein homologue TRP6 is the essential component of vascular alpha(I)-adrenoceptor-activated $\mathrm{Ca}^{(2+)}$-permeable cation channel. Circ Res 200I, 88(3):325-332.

25. Yu Y, Sweeney M, Zhang S, Platoshyn O, Landsberg J, Rothman A, Yuan JX: PDGF stimulates pulmonary vascular smooth mus- 
cle cell proliferation by upregulating TRPC6 expression. Am J Physiol Cell Physiol 2003, 284(2):C316-330.

26. $\mathrm{Ng}$ LC, Gurney AM: Store-operated channels mediate $\mathrm{Ca}^{(2+)}$ influx and contraction in rat pulmonary artery. Circ Res 200I, 89(10):923-929.

27. Dietrich A, Kalwa H, Fuchs B, Grimminger F, Weissmann N, Gudermann $T$ : In vivo TRPC functions in the cardiopulmonary vasculature. Cell Calcium 2007, 42(2):233-244.

28. Hill AJ, Hinton JM, Cheng H, Gao Z, Bates DO, Hancox JC, Langton PD, James AF: A TRPC-like non-selective cation current activated by alpha I-adrenoceptors in rat mesenteric artery smooth muscle cells. Cell Calcium 2006, 40(I):29-40.

29. Kuwahara K, Wang Y, McAnally J, Richardson JA, Bassel-Duby R, Hill JA, Olson EN: TRPC6 fulfills a calcineurin signaling circuit during pathologic cardiac remodeling. J Clin Invest 2006, I I6(I 2):3|| $4-3 \mid 26$.

30. Guinamard $R$, Bois $P$ : Involvement of transient receptor potential proteins in cardiac hypertrophy. Biochim Biophys Acta 2007, I772(8):885-894.

31. Thebault S, Flourakis M, Vanoverberghe K, Vandermoere F, Roudbaraki $M$, Lehen'kyi V, Slomianny $C$, Beck B, Mariot $P$, Bonnal JL, et al.: Differential role of transient receptor potential channels in $\mathrm{Ca}^{2+}$ entry and proliferation of prostate cancer epithelial cells. Cancer Res 2006, 66(4):2038-2047.

32. El Hiani Y, Ahidouch A, Roudbaraki M, Guenin S, Brule G, OuadidAhidouch $\mathrm{H}$ : Calcium-sensing receptor stimulation induces nonselective cation channel activation in breast cancer cells. J Membr Biol 2006, 2 I I (2): I27-I37.

33. Ethier SP, Mahacek M, Gullick WJ, Frank TS, Weber B: Differential isolation of normal luminal epithelial cells and breast cancer cells from primary and metastatic sites using selective media. Cancer Res 1993, 53(3):627-635.

34. Parekh $A B$, Putney JW Jr: Store-operated calcium channels. Physiol Rev 2005, 85(2):757-810.

35. Dietrich A, Kalwa H, Rost BR, Gudermann T: The Diacylglycerolsensitive TRPC $3 / 6 / 7$ subfamily of cation channels: functionnal characterization and physiological revelance. Plugers Arch 2005, 45 I ( I): $72-80$.

36. Thebault S, Roudbaraki M, Sydorenko V, Shuba Y, Lemonnier L, Slomianny C, Dewailly E, Bonnal JL, Mauroy B, Skryma R, Prevarskaya N: Alphal-adrenergic receptors activate $\mathrm{Ca}(2+)$-permeable cationic channels in prostate cancer epithelial cells. J Clin Invest 2003, III(II):I69I-I70I.

37. Stringer BK, Cooper AG, Shepard SB: Overexpression of the Gprotein inwardly rectifying potassium channel I (GIRKI) in primary breast carcinomas correlates with axillary lymph node metastasis. Cancer Res 200I, 6 I (2):582-588.

38. Mello de Queiroz F, Suarez-Kurtz G, Stühmer W, Pardo LA: Ether à go-go potassium channel expression in soft tissue sarcoma patients. Mol Cancer 2006, 5:42. 2006 oct 5

39. Ding EL, Metha S, Fawszi WW, Giovannucci EL: Interaction of estrogen therapy wtih calcium and vitaminD supplementation on colorectal cancer risk: Reanalysis of Women's Health Initiative randomized trial. Int J Cancer 2007, I 22(8): I690-1694.

40. Lehen'kyi V, Flourakis M, Skryma R, Prevarskaya N: TRPV6 channel controls prostate cancer cell proliferation via $\mathrm{Ca}(2+) / \mathrm{NFAT}$ dependent pathways. Oncogene 2007, 26(52):7380-7385.

41. Vazquez SM, Mladovan AG, Perez C, Bruzzone A, Baldi A, Luthy IA: Human breast cell lines exhibit functional alpha2-adrenoceptors. Cancer Chemother Pharmacol 2006, 58(I):50-61.

\section{Pre-publication history}

The pre-publication history for this paper can be accessed here:

http://www.biomedcentral.com/1471-2407/8/125/prepub 